\title{
Geochemical analysis of the special clay deposit of Tamame de Sayago (Zamora)
}

\author{
ANDREA GARCÍA VICENTE ${ }^{1}$, EVA MANCHADO \\ MACÍAS ${ }^{1}$, ADRIÁN LORENZO HERNÁNDEZ ${ }^{1}$, JUAN \\ MORALES SÁNCHEZ MIGALLÓN ${ }^{1}$, EMILIA GARCÍA \\ ROMERO $^{2}$ AND MERCEDES SUÁREZ BARRIOS ${ }^{1}$ \\ ${ }^{1}$ University of Salamanca \\ ${ }^{2}$ Complutense University of Madrid \\ Presenting Author: andrea_gar@usal.es
}

The Tamame de Sayago special clay deposit is part of the Central-Iberian Zone of the Iberian Massif, as proposed by Juliver et al., (1972)[1]. Manchado (2012) proposes the origin of the deposit as a result of two different processes [2]. First one, kaolinitization by meteoric alteration of granite, to what Manchado called Homogeneous Alteration Zones. The second process is bentonitization by hydrothermal alteration of previously kaolinitized granite, known as Heterogeneous Alteration Zones. The difference between the two zones settle in the relative percentages of kaolinite and smectite, being kaolinite the main component of Homogeneous Alteration Zone and smectite of Heterogeneous Alteration Zone.

The analysis of the geochemistry of major, minor and trace elements is very useful in order to study the origin of kaolin deposits. The values of the $\mathrm{SiO}_{2} / \mathrm{MgO}$ ratio of the Homogeneous Alteration Zones are high due to the silica content. However, $\mathrm{Mg}$ content is low since this element is mobilized with the weathering of the granites. The $\mathrm{SiO}_{2} / \mathrm{MgO}$ ratio decreases considerably in the Heterogeneous Alteration Zone as a consequence of the increase in $\mathrm{Mg}$ content, linked to the presence of smectites (Manchado, 2012) [2]. The low ratio values of $\mathrm{SiO}_{2} / \mathrm{MgO}$ and $\mathrm{Al}_{2} \mathrm{O}_{3} / \mathrm{MgO}$ in the Heterogeneous Alteration Zone indicate that the composition of the fluids that originated the hydrothermal alteration was relatively rich in $\mathrm{Mg}$. Granites from the Homogeneous Alteration Zone are poor in $\mathrm{MnO}$ and $\mathrm{Na}_{2} \mathrm{O}$, as well as in $\mathrm{K}, \mathrm{Fe}$ and Ti.

The analysis of trace elements allows to conclude that Homogeneous Alteration Zone are affected by meteoric alteration and Heterogeneous Alteration Zone has an important hydrothermal influence, as proposed by (Manchado, 2012) for the genesis of the deposit [2].

Financial support of the SA0107P20 (Consejería de Educación, Junta de Castilla y León, Spain) PID2019106504RB-I00 (Ministerio de Ciencia e Innovación, Spain) and projects is acknowledged.

[1]Juliver, M., Fontbote, J.M., Ribeiro. A. y Conde, L. (1972): Mapa tectónico de la Península Ibérica y Baleares a escala 1:100.000. IGME, Memoria explicativa, 113p.

[2]Manchado Macías, E. (2012): Arcillas Especiales de Tamame de Sayago (Zamora): Mineralogía, Génesis y Propiedades. Tesis Doctoral, Univ. Salamanca.573 pp. 